\title{
Rozczarowanie niespełnionymi obietnicami - dorastanie w prowincjonalnym macedońskim mieście
}

\section{Abstract \\ Disenchantment with Unfulfilled Promises - Adolescence in a Provincial Macedonian Town}

In the last decade, significant social movements have emerged in Southeast Europe. Citizens, mostly in the capital cities, objected to the corrupt political class and their criminal entanglements, privatization of public space, environmental degradation or NATO military pacts. As a result, we witnessed violent clashes between law enforcement and protesters, resignations of politicians and revolts. However, not everyone was protesting and - as shown in the case of Macedonia - not all citizens supported new pro-European transformation. This paper is about those who decided not to engage in protests and passively observe protest during so called the "Colorful Revolution" in Macedonia. The starting points for my analysis are the following questions: in which terms can we describe human existence when their agency is invisible or does not take affective from? Why instead of political engagement does political indifference arise? Drawing on the terms such as hope and disenchantment, I argue that passiveness and political apathy, which I observed among my research participants, was caused by the disenchantment with unfulfilled promises carried out by independence of Macedonia in 1991.

Keywords: Macedonia, transformation, disenchantment, hope, adolescence 


\section{Wstęp}

Na początku maja 2016 roku wróciłem do Tetowa po krótkiej nieobecności. Siedząc w cukierni, dostrzegłem protestujących z transparentem „To wszystko dla Macedonii” („Za Makedonija se rabota”). W tłumie przeważali etniczni Macedończycy po 40. roku życia. Grupa liczyła około 200 osób niosących w rękach macedońskie flagi, a w ustach trzymających gwizdki. Pomyślałem, że jestem świadkiem lokalnego ruchu sprzeciwu wobec rządzącej pod przywództwem Nikoły Gruewskiego partii VMRO-DPMNE${ }^{1}$. Postanowiłem przyłączyć się do marszu i podpytać manifestantów o ich motywacje do wyjścia na ulicę. Nie uzyskałem jednak odpowiedzi na nurtujące mnie zagadnienia, za to spotkałem się z nieufnością moich rozmówców. Zostałem obdarzony podejrzliwymi spojrzeniami i pytaniami: skąd jestem, dla kogo pracuję i czy płaci mi George Soros². Tłumacząc swoją obecność w kraju, wówczas jeszcze nazywanym Macedonią ${ }^{3}$, kontynuowałem marsz ulicami miasta. Po kilku minutach drogi w ogródku pobliskiej kawiarni dostrzegłem moich sąsiadów i zarazem partnerów badawczych - młodych Macedończyków, siedzących wygodnie i pijących kawę. Jeden z nich, 26-letni bezrobotny muzyk, rozpoznał mnie i przekrzykując tłum, przestrzegł mnie słowami: „Ajde Roki! Ne se zamaraj so politikata!” („Roki! Nie baw się w politykę!”). Nic nie odpowiedziałem, ale lekko zmieszany podążyłem za tłumem. Ten, ku mojemu zdumieniu, nie szedł w kierunku lokalnej siedziby prezydenta państwa, ale w stronę miejscowego oddziału opozycyjnej partii SDSM ${ }^{4}$, gdzie stali kontrdemonstranci. Jeszcze większe zdziwienie wywołały u mnie hasła wykrzykiwane przez protestujących: „Nikoła, Nikoła, nikt ci nic nie może [zrobić - przyp. R.R.]!”. Wówczas zrozumiałem, że nie jest to protest przeciw rządowi, ale manifestacja poparcia dla niego.

Zaskoczyło mnie, że demonstracja poparcia dla rządu odbyła się w czwartek, czyli w dniu akcji protestacyjnej Sekoj cetvrtok (W Każdy Czwartek). Sekoj cetvrtok co tydzień mobilizował ludzi w całym kraju do wyjścia na ulicę i wyrażania swojego sprzeciwu wobec partii rządzącej. Od 2014 roku w wówczas jeszcze Byłej Jugosłowiańskiej Republice Macedonii odbywały się liczne protesty przeciwni-

1 Wewnętrzna Macedońska Organizacja Rewolucyjna - Demokratyczna Partia Macedońskiej Jedności Narodowej.

2 Amerykański inwestor giełdowy pochodzenia węgiersko-żydowskiego, filantrop, sponsor społeczności obywatelskiej w Europie Centralnej i Południowo-Wschodniej. W Macedonii uważany jest za przeciwnika konserwatywnych rządów VMRO-DPMNE.

3 Od uzyskania niepodległości do lutego 2019 roku ta była jugosłowiańska republika nosiła nazwę Macedonia, a na arenie międzynarodowej - Była Jugosłowiańska Republika Macedonii (FYROM). Na początku 2019 roku macedoński parlament przegłosował zmiany w konstytucji wypracowane $\mathrm{w}$ ramach tzw. porozumienia znad jeziora Prespa. Założeniem tego porozumienia było uregulowanie relacji macedońsko-greckich, co zaowocowało zmianą nazwy kraju na Macedonia Północna w lutym 2019 roku.

4 Socjaldemokratyczny Związek Macedonii. 
ków rządu premiera Nikoły Gruewskiego. Protesty, znane jako Šarena revolucija (Kolorowa Rewolucja) $)^{5}$, wywołało ujawnienie przez partię opozycyjną podsłuchów członków rządu Gruewskiego. Nagrania ujawniły bezprecedensową skalę inwigilacji obywateli Macedonii (również swoich kolegów partyjnych), instrumentalne wzniecanie konfliktów etnicznych, korupcję, nepotyzm oraz przestępstwa wyborcze i kryminalne. Społeczne oburzenie doprowadziło do największych demonstracji w całym kraju od uzyskania niepodległości Macedonii i blisko trzyletniego impasu politycznego. Protesty przeciwników rządu i kontrprotesty jego zwolenników gromadziły podobną liczbę uczestników. Obopólne oskarżenia oraz różne pomysły na rozwój kraju dwóch największych partii, wspierane przez reprezentantów Unii Europejskiej (UE), Stanów Zjednoczonych i Rosji, wzmagały wrażenie wielogłosu i heterogeniczność przekazu. Różnorodność, często sprzecznych, narracji politycznych, obiecujących przyszłość w różnych odcieniach postępu, budziła nie tylko nieufność wobec metanarracji (zob. Lyatord 1984: XXV), ale również wobec klasy politycznej i demokracji.

Nie do przecenienia w zaognianiu impasu politycznego oraz później w jego rozwiązywaniu była rola UE i USA. Kiedy unijny komisarz Johannes Hahn, rozczarowany niemożnością wypracowania porozumienia między rządzącą partią VMRO-DPMNE a partią opozycyjną SDSM, opuścił Macedonię, Ace, 27-letni student informatyki, zauważył: „,rzeczywiście, Hahn był rozczarowany, ale on zaraz wyjedzie, odpocznie w Brukseli i zrobi mu się lepiej. A my jesteśmy rozczarowani permanentnie i musimy z tym żyć". Rozczarowanie było jednym ze słów, które często powtarzało się $\mathrm{w}$ rozmowach $\mathrm{z}$ Macedończykami na temat otaczającej ich rzeczywistości.

W ostatniej dekadzie na Półwyspie Bałkańskim powstawały znaczące ruchy społeczne. Mieszkańcy, głównie stolic, protestowali przeciwko korupcji klasy politycznej i powiązaniom z grupami kryminalnymi, prywatyzacji przestrzeni publicznej, degradacji środowiska czy włączeniu do NATO. W rezultacie często dochodziło do rewolt albo dymisji w rządzie. $\mathrm{W}$ ostatnich latach powstało kilka opracowań antropologicznych i politologicznych na ten temat. Wśród nich można wymienić pracę Ilki Thiessen (2007), która pokazuje, że niepokoje społeczne są spowodowane upadkiem państwa socjalnego i oddalaniem się od Zachodu. Inne badania wskazują na niezadowolenie mieszkańców byłych jugosłowiańskich republik z klasy politycznej. Stef Jansen (2015) ukazuje niewydajność postdaytonowskich zdecentralizowanych rządów Bośni i Hercegowiny, które raczej przypominają brak rządów niż ich istnienie. Antropolog zaobserwował wśród mieszkańców Sarajewa zmęczenie obietnicami przystąpienia do UE, które wydaje się emblematyczne dla Serbii, Bośni i Hercegowiny, Kosowa czy Macedonii. W podobnym tonie rozczarowania decydentami politycznymi utrzymują swoje analizy inni badacze. Florian Bieber oraz Dario Brentin w pracy zbiorowej poświęconej

5 Nazwa Kolorowa Rewolucja wzięła się z obrzucania podczas protestów kolorową farbą neoantycznych budynków zbudowanych w ramach projektu Skopje 2014. 
ruchom społecznym na Bałkanach twierdzą, że przyczyną niezadowolenia społecznego jest poczucie krzywdy, jakie wywołuje władza, tak samo autorytarna, jak i demokratyczna, zarządzająca wspólnym dobrem, przestrzeniami publicznymi i państwem (Brentin, Bieber 2018: 1). Te i inne prace, choć znakomicie pokazują pogarszające się nastroje społeczne i wzrastające motywacje do protestów: rozczarowanie i poczucie porzucenia, w dużo mniejszym stopniu tłumaczą, dlaczego część społeczeństwa nie wychodzi na ulice.

Celem niniejszego tekstu jest zrozumienie, dlaczego młodzi Macedończycy z Tetowa, pomimo niezadowolenia z zastanej rzeczywistości, nie uczestniczą w publicznych protestach. Dlaczego nie chcieli walczyć z klientelistycznym systemem partyjnym i wspierać wejścia do UE i NATO, które niosą w krajach postsocjalistycznych wyobrażenie współczesności, europejskiej cywilizacji i demokracji (Thiessen 2007; Greenberg 2014). Tekst traktuje o tych, którzy postanowili się nie angażować i biernie obserwować protesty. Jednocześnie jest to historia o dążeniu do samodzielności u progu dorosłego życia w peryferyjnym, wieloetnicznym mieście - Tetowie ${ }^{6}$.

Tekst odpowiada na pytanie, w jaki sposób młodzi Macedończycy odnoszą się do zmian, które nastąpiły po rozpadzie Jugosławii, i jak postrzegają swoją podmiotowość polityczną u progu wejścia do globalnych struktur politycznych i militarnych. Opierając się na danych empirycznych uzyskanych w ramach badań, rozwijam tezę, że apatia polityczna wśród dorastających mężczyzn w Tetowie jest spowodowana rozczarowaniem i utraconymi nadziejami, jakie niosła transformacja ustrojowa, oraz powątpiewaniem w suwerenność Macedonii. Niechęć do wyrażenia swojego sprzeciwu jest natomiast rezultatem klientelizmu etniczno-partyjnego, który wywołuje strach przed aktywnością polityczną.

\section{Metodologia}

Badania terenowe w Macedonii prowadziłem w 2015 i 2018 roku. Był to okres napięć politycznych: dochodziło do rebelii i długotrwałych protestów, angażujących tysiące obywateli, głównie etnicznych Macedończyków ${ }^{7}$. Zastaną podczas badań terenowych sytuację można scharakteryzować jako pełną realnego i wyimaginowanego strachu. Był on spowodowany czynnikami zewnętrznymi: atakami kosowskiej grupy zbrojnej w maju 2014 roku, ingerencją UE, Stanów

6 Według spisu powszechnego z 2002 roku większość w Tetowie stanowią Albańczycy (55\%), a mniejszość Macedończycy (35\%). Warto również wspomnieć o mniejszych społecznościach, takich jak Turcy, Serbowie i Romowie (10\%); www.stat.gov.mk/pdf/kniga_13.pdf (dostęp: 22.11.2019). Dane ze spisu powszechnego nie odzwierciedlają rzeczywistej mozaiki etnicznej miasta na niekorzyść społeczności albańskiej.

7 Mniejszość albańska również protestowała, ale przy innych okazjach, między innymi przeciwko złej jakości powietrza w mieście. 
Zjednoczonych czy Rosji w krajową politykę, napływem migrantów zza południowej granicy, a także czynnikami wewnętrznymi: aktywnością służb wywiadowczych ${ }^{8}$, zagrożeniem konfliktami politycznymi i zbrojnymi oraz niepewnością zatrudnienia. Dynamiczna sytuacja społeczno-polityczna, choć niezwykle interesująca poznawczo, nie sprzyjała prowadzeniu badań (Rydzewski 2018).

Podczas pobytu $\mathrm{w}$ Tetowie wielokrotnie spotykałem się $\mathrm{z}$ odmową udzielenia wywiadu nawet wśród osób, z którymi znałem się od lat. Moi partnerzy ${ }^{9}$ badawczy tłumaczyli się: „Jas ne sum za toa” („Nie nadaję się do tego”), „Ne me interesira polityka” („Nie interesuję się polityką"). Inni przekładali spotkania w nieskończoność. Kiedy już udało nam się umówić na spotkanie, tłumaczyłem moim respondentom, co mnie interesuje i w jaki sposób będę wykorzystywał informacje z wywiadów. Wówczas pytano mnie, dlaczego przyjeżdżam i badam zmiany społeczne w Tetowie oraz skąd wzięło się moje przekonanie, że w Tetowie istnieją problemy między Albańczykami i Macedończykami ${ }^{10}$. Zadawano mi pytania, dla kogo nagrywam oraz gdzie zamierzam opublikować uzyskane informacje. Jeden z moich rozmówców zapytał mnie wprost, czy będę manipulował nagraniem na jego niekorzyść.

Metody badań etnograficznych powszechnie używane przez etnologów i antropologów kulturowych, takie jak pozyskiwanie respondentów przez polecenie, tzw. metodą kuli śnieżnej, oraz nagrywanie wywiadów na dyktafon, podczas moich badań się nie sprawdzały. Podejrzliwość w stosunku do mojej osoby, strach przed udzieleniem wywiadu bardzo utrudniały pracę badawczą. Jedną z niewielu możliwości zrozumienia świata młodych Macedończyków wchodzących w dorosłe życie była metoda cienia (shadowing) albo wspólne spędzanie czasu wolnego. Moi partnerzy badawczy chętniej dzielili się swoimi spostrzeżeniami podczas porannych sobotnich spacerów do lokalnego źródła wody albo przejażdżek rowerowych, posiłków w restauracjach, wieczorów przy rakii. W ramach wspólnego spędzania wolnego czasu uzyskałem dostęp do często intymnych sfer życia, choć bardzo wyrywkowo, co utrudniało budowanie ich ciągłej narracji.

\section{Zrozumieć rozczarowanie}

Thiessen w książce Waiting for Macedonia: Identity in a Changing World (2007), poświęconej inżynierkom żyjącym w Skopje u progu rozpadu Jugosławii i uzy-

8 Dowodem obaw przed aktywnością służb specjalnych są badania statystyczne, które pokazują, że w latach 2015 i 2018 od 45\% do 52\% mieszkańców Macedonii uważało, że ich rozmowy telefoniczne są podsłuchiwane; https://www.iri.org/sites/default/files/iri_macedonia_july_2018_ poll_public_final.pdf (dostęp: 18.10.2018).

9 Moi partnerzy badawczy w momencie rozpoczęcia badań etnograficznych mieli od 22 do 35 lat, mieszkali razem z rodzicami i po ukończeniu nauki doświadczyli długich okresów bezrobocia.

10 Pytanie o relacje międzyetniczne często padało podczas poprzednich wyjazdów terenowych. 
skania niepodległości Macedonii, zauważyła wśród nich brak wiary w rozwiązanie zewnętrznych i wewnętrznych konfliktów w Macedonii. Jednocześnie jej rozmówczynie wyrażały nadzieję, że kiedyś obywatele i obywatelki Macedonii zostaną uznani jako naród i staną się częścią UE.

Jak sugeruje Thiessen, nadzieje, jakie niosła niepodległość Macedonii, rodziły się w bólach radykalnego zubożenia i wojen domowych w sąsiednich byłych republikach. Nadzieja w badaniach antropologicznych jest ściśle powiązana z oczekiwaniem. Valeria Procupez definiuje nadzieję jako oczekiwanie podczas działania (Procupez 2015: 63). Nadzieja, jak twierdzi Jarrett Zigon (2018: 65), nic nie gwarantuje, ale sugeruje, że coś może się jeszcze zmienić. A zatem - jak zauważył Jansen - bez pewnej dozy nieoczywistości nadzieja nie występuje (Jansen 2016: 459). Mieć nadzieję oznacza bycie zorientowanym na przyszłość i gotowym na oczekiwanie, które w swojej wariacji może być aktywne albo pasywne (zob. Bandak, Janeja 2018), w przeciwieństwie do rozczarowania, które jest pasywne, bo jest reakcją na akty dokonane. Nadzieja jest wyrażana poprzez oczekiwanie na zmiany, domaga się cierpliwości. Ta jest definiowana przez Andreasa Bandaka i Manpreet K. Janeję jako „postawa polityczna, która wymaga zmiany perspektywy z bezpośredniej na długoterminową" (Bandak, Janeja 2018: 8). Cierpliwość jest również rozumiana jako aktywne zaangażowanie, oparte na zaufaniu do władzy starającej się zmienić rzeczywistość według wcześniej przedstawionego politycznego planu. Niemniej, jak przekonuje Martin Demant Frederiksen, społeczne zmiany rzadko, jeśli w ogóle, zachodzą w ciągu nocy, co dla wielu reprezentacji politycznych, które doszły do władzy na kanwie obietnic i nadziei, jest zgubne. Brak zmian idących za politycznymi obietnicami może przekuć się w niepewność, pasywność, apatię społeczną i brak wiary w reprezentacje polityczne (Frederiksen 2018: 173).

Rozczarowanie w kontekście Macedonii jest doświadczeniem niezrealizowanych nadziei i niespełnionych obietnic, jakie niosła transformacja, oraz brakiem wiary, że mogą one zostać kiedykolwiek zrealizowane. Rozczarowanie, które zaobserwowałem w terenie, jest bliskie Nietzscheańskiej koncepcji „śmierci boga”. Ta jest rozumiana jako odrzucenie wiary $\mathrm{w}$ dotychczasowe transcendentne wartości i ideały, jak również podważa wagę autorytetów (Metzger 2010: 115). Korupcja i nepotyzm polityków poskutkowały zwątpieniem w przedstawicieli władzy, któremu towarzyszył brak przekonania co do poprawy sytuacji w kraju. Wśród moich rozmówców powszechna była opinia, że wraz ze zmianą władzy z konserwatywno-nacjonalistycznej partii VMRO-DPMNE na socjaldemokratyczną partię SDSM nic się nie zmieni poza osobami, które zajmują stołki w administracji publicznej, słowem nastąpi zmiana bez zmian (zob. Frederiksen 2018). Brak zaufania do władz państwowych podważał suwerenność Macedonii i przenosił nadzieję na poprawę sytuacji w stronę UE, a ta zawodziła. Zawodziła w Kosowie czy Bośni i Hercegowinie. A zatem rozczarowanie jest pozbyciem się iluzji, że może być lepiej. 
Inny pogląd na rozczarowanie prezentuje Jessica Greenberg (2014) w swojej książce analizującej protesty we wrześniu 2000 roku w Serbii, a w konsekwencji obalenie reżimu Slobodana Miloševicia. Badaczka uważa, że rozczarowanie nie jest brakiem nadziei, możliwości czy rezultatem polityki, która miała miejsce w innym miejscu czy czasie. Antropolożka twierdzi, że jest wręcz przeciwnie (Greenberg 2014: 9). Rozczarowanie jest złożoną polityczną i afektywną formą w czasie rzeczywistym, która pozwala zrozumieć aktywność polityczną. Greenberg uważa, że analizując rozczarowanie, łatwo popaść w binarne opozycje nadziei i braku nadziei albo bezsilności, która implikuje "negatywne” afektywne doświadczenie (Greenberg 2014: 8). Jej praca jest odzwierciedleniem umiejętności antropologów w odnajdywaniu sprawczości wśród grupy badawczej, nawet wśród tych, którzy żyją w najbardziej niesprzyjających warunkach pod opresyjnymi rządami. Niemniej jednak, choć spostrzeżenia tej antropolożki są bardzo inspirujące, to doświadczenia młodych Macedończyków z peryferyjnego miasta wskazują na poczucie rozczarowania, które nie przekłada się na polityczną aktywność. Toteż zastanawiające jest, w jakich kategoriach opisywać ludzką egzystencję, kiedy sprawczości brak albo jest przysłaniana przez konformizm czy nihilizm. Jak opisać doświadczenie młodych Macedończyków obserwujących przedłużającą się transformację, która zamieniła się w regres? Dlaczego w miejscu cierpliwości formowała się frustracja, a w miejscu zaangażowania politycznego obojętność? Czy rozczarowanie młodych mieszkańców Tetowa może nieść za sobą aktywną postawę?

\section{Nadzieja rodząca się w bólu transformacji}

Macedonia po uzyskaniu niepodległości 8 sierpnia 1991 roku, na tle byłych republik Jugosławii, była relatywnie stabilna politycznie. Nie doszło do wojny domowej, jak w Bośni i Hercegowinie, Serbii czy Chorwacji, niemniej sytuacja ekonomiczna w tej, i tak już najbiedniejszej, byłej republice zdecydowanie się pogorszyła. Początek lat 90 . XX wieku był okresem burzliwej transformacji politycznej i społecznej. Do destabilizacji kraju przyczynił się również konflikt wewnętrzny. W 2001 roku albańscy partyzanci, wsparci przez Armię Wyzwolenia Kosowa, zaatakowali macedońskie służby bezpieczeństwa, domagając się zwiększenia praw dla mniejszości albańskiej w Macedonii. Choć konflikt trwał pięć miesięcy i nie zaangażował ludności cywilnej, to trwale wpisał się w debatę publiczną o relacjach etnicznych w kraju (Neofotistos 2012).

Thiessen (2007) na łamach swojej książki przekonuje, że zmiany ustrojowe, poza życiem politycznym, wpłynęły również na subiektywne doświadczenia życia codziennego mieszkańców Macedonii. Codzienne życie Macedończyków było wypełnione obawami przed wojną, bezradnością, rozczarowaniem i kurczącą się wolnością. Jak udowadnia antropolożka, młodzi ludzie wchodzący na rynek 
pracy zostali pozbawieni możliwości, jakie mieli przedtem. Wysokie stypendia były anulowane, nie przyznawano już lokali socjalnych emigrującym ze wsi do miast studentom (Thiessen 2007: 81). Nie tylko zmniejszyły się możliwości nauki i pracy w Macedonii czy w innych byłych republikach Jugosławii, ale również za granicą. Sankcje, nałożone przez kraje ościenne, unieważniły przywilej bezwizowej podróży do krajów Europy Zachodniej, jakie dawał jugosłowiański czerwony paszport (Thiessen 2007: 101). Rozpad Jugosławii zmniejszył niezależność młodych ludzi. Wielu $\mathrm{z}$ nich nie miało szansy wyprowadzić się z domu rodzinnego, a ci, którzy już to zrobili, często musieli ponownie zamieszkać ze swoimi rodzicami (Thiessen 2007: 87). Skutkowało to ograniczaniem swobody młodych ludzi i wzrostem generacyjnych nieporozumień w rodzinie. Rozczarowanie wiązało się również z rozpadem mitu Jugosławii jako państwa, które łączyło poza różnicami etnicznymi i narodowościowymi.

Rozpad Jugosławii przyniósł w Macedonii zubożenie społeczeństwa i upadek przemysłu. Jak wynika z badań Fabia Mattiolego (2016), międzynarodowe instytucje wywierały naciski na nowo powstałe państwo, by dążyło do integracji z globalną ekonomią kapitalistyczną. Podwalinami tego procesu była prywatyzacja. Wprowadzone reformy przyczyniły się do wzrostu bezrobocia ${ }^{11}$, które do dzisiaj utrzymuje się powyżej $22 \%{ }^{12}$, a wśród ludzi w wieku 15-24 lat sięga $47 \%{ }^{13}$. W rezultacie reform gospodarczych wiele osób zostało wykluczonych z rynku pracy i pozbawionych opieki państwa.

Dorastający w Tetowie Macedończycy z trudem mogli znaleźć jakąkolwiek pracę, ta legalna, w wyuczonym zawodzie była nieosiągalna. Moi rozmówcy ratowali się zatrudnieniem w sektorze usługowym, głównie w kasynach, barach albo sklepach. Zarabiali równowartość 150-250 euro miesięcznie. Aleksander, 27-letni mężczyzna, pracował w kasynie na umowę o dzieło 6 dni w tygodniu po 10 godzin dziennie. W ciągu roku, podobnie jak inni moi rozmówcy, miał 20 dni wolnego i nie przysługiwały mu dodatkowe wolne dni z okazji świąt religijnych i narodowych. Zarobione pieniądze nie pozwalały mu się usamodzielnić. Wystarczały one na wsparcie rodzinnego budżetu, papierosy, alkohol, zakłady bukmacherskie i na spotkania w kafanach ${ }^{14}$.

\section{Doświadczenie zbyt szybkiego regresu}

Reinhart Koselleck (2004) zauważa, że rozwój pojawia się w momencie, kiedy zmienia się relacja między doświadczeniem a oczekiwaniami. Oczekiwania co do

11 Najwyższe bezrobocie wystąpiło w 1998 roku i osiągnęło 36\%.

12 https://www.theglobaleconomy.com/Macedonia/Unemployment_rate/ (dostęp: 18.10.2018).

13 Macedońskie Biuro Statystyczne, http://www.stat.gov.mk (dostęp: 18.10.2018).

14 Kafana to macedońska restauracja, która serwuje lokalne jedzenie, często w akompaniamencie muzyki na żywo. 
przyszłości są generowane na podstawie doświadczeń z przeszłości, ale wraz ze wzrostem przekonania w nieuchronność postępu to się zmienia (Koselleck 2004: 19-22). To, co przynosiła przyszłość moim rozmówcom, diametralnie odbiegało od doświadczeń ich rodziców w czasach dorastania w Jugosławii: podróżowania, wyjazdów na zagraniczne stypendia, stabilnej pracy, modernizacji kraju. Malował się przed nimi rozwój w formie rozkwitu kontaktów społecznych i karier zawodowych. Atmosfera w socjalistycznej Jugosławii była charyzmatyczna, tak długo, jak długo obywatele wierzyli w rewolucyjne zmiany (Greenberg 2014: 27). Choć wiele $\mathrm{z}$ tych wspomnień jest dzisiaj zdominowanych przez tzw. jugonostalgię, to są one odnośnikami w narracjach moich rozmówców i pokazują różnice między warunkami, w jakich dorastali młodzi Macedończycy w Tetowie i ich rodzice. Jugonostalgia, jak przekonuje Maja Maksimović, jest zbiorem wyselekcjonowanych wspomnień o czasach świetności Jugosławii (Maksimović 2017: 1068), dlatego nie przywołuje prawdziwego wspomnienia tego, jak wyglądało życie w czasach Jugosławii, ale jego wyidealizowany obraz. Warto zaznaczyć, że wspomnienia Jugosławii moich respondentów nie mają podstawy biograficznej, lecz są zapożyczone z historii rodziców i wytworów popkultury, takich jak filmy i muzyka, co w literaturze naukowej nazywa się pamięcią protetyczną (Landsberg 2004: 20). Jugonostalgia dorastających Macedończyków jest wyrazem rzeczy i wartości, o których myślą nostalgicznie, za którymi tęsknią, ale których nie doświadczyli. W przypadku mieszkańców Tetowa jest to ekonomiczny dobrobyt, solidarność poza podziałami etnicznymi, bezpieczeństwo oraz bogate życie kulturalne i społeczne. Jugonostalgia jest ważnym elementem, pomocnym w zrozumieniu rozczarowania wśród dorastających Macedończyków, ponieważ jest ona zorientowana w kierunku fantazji dotyczących przeszłości (Maksimović 2017: 1068), czyli wszystkich tych możliwości dostępnych dla ich rodziców, a dla nich już nieosiągalnych.

Moi rozmówcy znaleźli się w pułapce między centralnie sterowaną ekonomią a ekonomią kapitalistyczną, niekończącą się transformacją. Czasy „pomiędzy” rozpadem Jugosławii a ewentualnym oddalającym się członkostwem w UE były naznaczone drapieżną prywatyzacją, próbami redefiniowania tożsamości narodowej, dostosowania do globalnej ekonomii i sojuszy militarnych, które przyniosły rozczarowanie, frustrację, poczucie regresu, niepewność i apatię polityczną. Okres przechodzenia $\mathrm{z}$ totalitarnego reżimu do rzekomej wolności i demokracji był naznaczony rozpadem nie tylko gospodarki, ale i transcendentalnych wartości, skutkował przerażeniem i przygnębieniem dużej części społeczeństwa.

To, co odróżnia czas „pomiędzy” w Tetowie od tego, co się działo w niezręcznie brzmiącym w języku polskim "międzyczasie” (meantime) w Sarajewie, a co zaobserwował Jansen (2015), to poczucie ruchu. W Bośni i Hercegowinie zmiany nie postępują wystarczająco szybko (not moving well enough). Obserwator postdaytonowskiej rzeczywistości opisuje ją jako zamrożoną, zatrzymaną w czasie (Jansen 2015: 53). Tymczasem w Tetowie zmiany następują zbyt szybko i w złym kierunku. Młodzi Macedończycy mają poczucie cofania się, które przybiera for- 
mę destrukcji w wyniku przeciążenia infrastruktury miejskiej, pogorszenia warunków pracy i opieki społecznej czy administracji publicznej. Goce, 38-letni samotny mężczyzna, z wykształcenia prawnik, powiedział mi:

Widzisz, jaki krok zrobiliśmy w ciągu 30 lat. Gdyby to się wydarzyło w ciągu 70 lat, nikt by tych zmian nie zauważył, ale to się stało tak szybko. Bum! Zamykanie fabryk, firmy z zagranicy zaczęły kupować to, co zostało z naszego przemysłu. My, Macedończycy, zostaliśmy tylko z jedną państwową firmą w całym kraju, reszta przepadła: Tetex - przepadł, Jugohrom - przepadł, Electroplastika - przepadła... Hala sportowa, która była wybudowana na wzór hali olimpijskiej w Sydney, została podzielona i podnajęta prywatnym dzierżawcom.

Prędkość, z jaką nastąpiły zmiany w życiu miejskim, spotęgowała poczucie nie tyle stagnacji, ile regresu, za który obwinia się skorumpowane elity polityczne i biznesowe.

Od momentu uzyskania niepodległości władzę w Macedonii sprawowały na zmianę dwa ugrupowania polityczne: VMRO-DPMNE oraz SDSM. W 2006 roku partia SDSM, która przeprowadziła dramatyczną w skutkach prywatyzację przemysłu, straciła władzę. Następczyni, partia VMRO-DPMNE, kontynuowała reformę kraju, choć w nieco innym stylu. Ich flagowy projekt Skopje 2014 miał na celu nie tylko przebudowę stolicy w neoantycznym stylu, ale również „antykwizację" tożsamości Macedończyków, czyli przebudowanie tożsamości narodowej, tak aby łączyła antyczno-macedońskie geny oraz antysłowiańskie dziedzictwo kulturowe (Majewski 2013). Autorzy tego projektu tożsamościowego obiecywali zmianę oblicza Macedonii, nadanie jej prawdziwie europejskiego szyku, a tym samym wzrost dumy narodowej oraz zwiększenie atrakcyjności kraju dla obcokrajowców (Graan 2013: 61) ${ }^{15}$. Równolegle z projektem „antykwizacji” tożsamości słowiańskich Macedończyków były wprowadzane reformy, który miały przyciągnąć do Macedonii inwestorów zagranicznych: obniżono koszty pracy, ograniczono prawa pracownicze, obniżono podatek dla firm i osób prywatnych do stałej stawki $10 \%$, utrzymywano najniższą płacę $\mathrm{w}$ regionie na poziomie 143 euro $^{16}$. Mimo niskiego wynagrodzenia wiele osób zatrudnionych było w szarej strefie, bez ubezpieczenia socjalnego i emerytalnego. Po przejęciu władzy przez SDSM, poprzedzonym Kolorową Rewolucją, Macedonia wkroczyła w kolejny etap strukturalnych zmian obiecujących jej zbliżenie do UE i NATO pod nową nazwą Macedonia Północna.

$\mathrm{Na}$ lokalnym tetowskim poziomie transformacja ustrojowa wyglądała nieco inaczej. Polityka „antykwizacji” nie odcisnęła znaczącego piętna na sferze symbolicznej Tetowa ${ }^{17}$. Było to spowodowane utrzymywaniem władzy lokalnej w rękach albańskich partii. Niemniej przedarł się jeden z jej elementów - wymazywanie

15 Ta polityka tożsamościowa interpretowana jest jako reakcja na odrzucenie kandydatury Macedonii do uzyskania członkostwa w NATO (Vangeli 2011) albo jako zmiana wizerunku państwa w celu przyciągnięcia zagranicznego kapitału (Graan 2013).

16 Dla porównania w Albanii jest to 160 euro, w Kosowie 170 euro, a w Grecji 683 euro.

17 Po upadku Jugosławii albańskie władze usunęły z przestrzeni miasta pomniki i nazwy ulic, które nawiązywały do socjalistycznych rewolucjonistów. Równocześnie otwarto kilka centrów han- 
znaków nawiązujących do spuścizny socjalistycznej Jugosławii. Poza tym Tetowo zostało pozbawione jakichkolwiek inwestycji infrastrukturalnych. Zona industrialna nie przyciągnęła zagranicznych ani lokalnych przedsiębiorców, poza jedną firmą produkującą fotele samochodowe. Biznesy, które powstały w okolicach Tetowa po 1992 roku, zostały założone głównie przez powracających z emigracji Albańczyków (Rydzewski [w druku]). Jednak upadł nie tylko przemysł ciężki, ale również życie kulturalne miasta. Wszystkie kina w Tetowie zamknięto, a lokalny dom kultury tylko okazjonalnie wystawiał sztuki teatralne. Podobny los spotkał obiekty sportowe i pobliski ośrodek sportów zimowych ${ }^{18}$. W przeciwieństwie do instytucji kultury i obiektów sportowych kwitną kasyna i zakłady bukmacherskie, które są jedną z niewielu rozrywek w Tetowie.

Po upadku Jugosławii pojawiła się pustka w życiu miejskim i zawodowym. Została ona zagospodarowana przez albańską politykę tożsamościową oraz klientelizm partyjny i etniczny, który objawia się osobliwym mariażem elit politycznych i biznesowych, popierającym i protegującym swoich działaczy w zamian za głosy i polityczną lojalność. Tę asymetryczną zależność elit i lokalnej społeczności Scott Radnitz nazywa „subwersywnym klientelizmem”, który jest objawem słabości państwa (Radnitz 2010). Warto podkreślić, że partie polityczne są podzielone wzdłuż linii etnicznych, a następnie względem reprezentacji interesów danych grup politycznych. Jest to między innymi spowodowane zinstytucjonalizowaniem etniczności (institutionalizing ethnicity), czyli reprezentacji grup etnicznych w instytucjach państwowych, w tym w ustawodawstwie, władzy wykonawczej, sądownictwie i administracji publicznej (Bieber 2004: 2). Zinstytucjonalizowana etniczność w praktyce przekłada się na słabą międzyetniczną kooperację i wyklucza $\mathrm{z}$ podziału władzy mniejszości etniczne na lokalnym poziomie $\mathrm{w}$ zdominowanych przez mniejszość albańską ${ }^{19}$ gminach (opštini).

Neoliberalne reformy, które miały modernizować kraj, przyniosły odwrotny skutek. Nagła i często nielegalna urbanizacja Tetowa, prywatyzacja przestrzeni publicznej bez planu zagospodarowania przestrzennego i równoległej rozbudowy infrastruktury komunalnej oraz brak inwestycji w przestarzały przemysł pogorszyły standard życia w tej części Macedonii. Obok codziennych przerw w dostawie wody oraz rosnących rachunków za energię mieszkańcy zmagali się z fatalną jakością powietrza, przekraczającą dziesięciokrotnie dopuszczalne normy ustanowione przez Światową Organizację Zdrowia. Smog był widoczny podczas mojego pierwszego pobytu w Tetowie, jesienią 2009 roku. Wówczas nieliczni spacerowicze

dlowych, które miały świadczyć o modernizacji kraju i wejściu do zglobalizowanej gospodarki oraz aspiracji włączenia obywateli Macedonii do zachodniej klasy średniej (zob. Mattioli 2016).

18 Ostoją instytucji szerzących sport są kluby górskie, które łączą pasjonatów przyrody i trekkingów.

19 Mimo że porozumienie ochrydzkie wyklucza możliwość terytorialnych rozwiązań dla kwestii etnicznych i Albańczycy w północno-zachodniej Macedonii nie mają całkowitej autonomii, decentralizacja władzy daje poszczególnym regionom samorządność. To przekłada się na pewną niezależność grup etnicznych dominujących w regionach. 
chodzili z siatkami, które rozkładali na ławkach, aby nie pobrudzić sobie ubrań zalegającym wszędzie szarym pyłem. Toksyczny swąd docierał do wnętrz mieszkań, przenikał odzież i włosy każdego, kto chociaż na chwilę wyszedł z domu. Ciężka zawiesina unosząca się nad miastem utrudniała nawet tak prozaiczne czynności jak podbiegnięcie do autobusu. Już ta niewielka aktywność fizyczna skutkowała bólem w klatce piersiowej.

Źródło zanieczyszczenia powietrza było tematem sporów. Według albańskiej pozarządowej organizacji Eco Guerilla - walczącej z zanieczyszczeniem środowiska w Tetowie - za zatruwanie powietrza odpowiedzialny jest głównie Jugohrom sprywatyzowane zakłady zajmujące się produkcją żelazostopów, położone $20 \mathrm{~km}$ od Tetowa. Nie bez znaczenia jest tutaj fakt, że huta, która emitowała 13 ton pyłu dziennie, leży we wsi Jegunovce, zdominowanej przez Macedończyków. Tymczasem według macedońskich respondentów zła jakość powietrza jest spowodowana wzrostem ruchu samochodowego, działaniem pieców domowych zasilanych niskiej jakości opałem oraz tlącego się nieoficjalnego wysypiska śmieci na obrzeżach Tetowa, za które odpowiadają albańskie władze miasta. Choć zanieczyszczenie powietrza było nie tylko rezultatem łupieżczej strategii sprywatyzowanego przemysłu czy braku kontroli państwa, ale także zubożenia i regresu technologicznego, to interesujące jest znaczenie, jakie mu nadawano. Semantyka smogu Tetowa stoi niejako w przeciwieństwie do tego wytwarzanego przez huty w Bor we wschodniej Serbii. Ten, jak udowadnia Deana Jovanović, pomimo pewnych obaw zdrowotnych, wyobraża nadzieję na stabilną osobistą i wspólnotową przyszłość, którą miał zapewnić, trujący okolice, państwowy przemysł (Jovanović 2018: 491). W Tetowie zanieczyszczenie powietrza symbolizuje regres, podziały etniczne i niewydajność administracji państwowej, która nie jest w stanie wymóc na kierownictwie huty zainstalowania filtrów powietrza.

Kiedy po kilku miesiącach relatywnie czystego powietrza, jesienią 2017 roku wróciła ciężka zawiesina smogu, Goce zauważył:

\footnotetext{
Miasto zmienia się w proch i śmieci, ludzie nie mają pieniędzy i muszą opalać domy piecem na drewno. Cofamy się! Jak byłem mały, to mieszkanie w bloku ogrzewaliśmy drewnem: do roku 1987 paliliśmy w piecach kuchennych drewnem. Potem przeszliśmy na kuchenki elektryczne i grzejniki. Pod koniec lat 90. przyszły klimatyzatory. W ostatnich latach wróciliśmy do tych starych kuchenek na drewno, bo ludzi nie stać na prąd.
}

Regres był również widoczny w sposobie, w jaki zmienia się miasto. Niemodernizowana infrastruktura miejska, dzika zabudowa oraz zabudowywanie terenów zielonych dla wielu moich rozmówców były dowodem na korupcję i nieudolność albańskich elit w zarządzaniu miastem. Brak inwestycji albo inwestycje, które rozpadały się jeszcze przed ich zakończeniem, przy równoczesnym starzeniu się infrastruktury zbudowanej za czasów Jugosławii, potęgowały wrażenie cofania się. Dla wielu Macedończyków punktami zwrotnymi w rozwoju miasta był konflikt 
w 2001 roku oraz reforma administracyjna z 2004 roku ${ }^{20}$, która pozwoliła Albańczykom na przejęcie władzy w całym okręgu administracyjnym Tetowa. Przywoływany wcześniej rozmówca, Aleksander, powiedział mi:

Pamiętam, jak przed 2001 rokiem jeździliśmy kolejką gondolową na kawę z Tetowa na Šapkę ${ }^{21}$. Przejazd kosztował 100 denarów. O godzinie 16.00 był ostatni kurs.... Po konflikcie wszystko się zmieniło. Albańczycy zyskali władzę, zaczęli budować domy bez pozwoleń. Teraz jest totalny chaos. [...] Cofamy się, Tetowo kiedyś było zielone i ciche. Tetowo przed 2001 rokiem było najlepszym miastem do życia w Macedonii. Mieliśmy mnóstwo parków. Miasto było zielone, cichsze i przyjemniejsze. Teraz państwo nie inwestuje w Tetowo, buduje się tylko w Skopje.

Jak pokazują powyższe wypowiedzi, poczucie egzystencjalnego regresu jest widoczne w rozmowach o Tetowie. Ten regres uwidacznia się przy skontrastowaniu Albańczyków i Macedończyków. Mobilność geograficzna i społeczna tych pierwszych jest dużo większa dzięki migracji, kontaktom transnarodowym oraz przekazom pieniężnym (Pichler 2009: 218, Rydzewski [w druku]). Ghassan Hage przekonuje, że podobnie jak istnieje wyimaginowana egzystencjalna mobilność, tak samo istnieje wyimaginowane egzystencjalne utknięcie (stuckedness), które generowane jest przez neoliberalną globalizację, a w szczególności przez niepewność na rynku pracy (Hage 2009: 3).

Mobilność, zarówno egzystencjalna, jak i geograficzna, podporządkowana jest neoliberalno-globalizacyjnemu projektowi, którego częścią jest powiększenie UE o kraje bałkańskie (Jansen 2009: 821). Mieszkańcy tych krajów od upadku Jugosławii znaleźli się w „poczekalni” w drodze na Zachód. Unia Europejska, konsekwentnie wykorzystując swoją asymetryczną władzę, utrzymuje Macedonię w poniżającej pułapce peryferyjności. Wytycza punkty, które Macedonia, jako kraj kandydujący do UE, musi wypełnić w drodze do członkostwa, przy jednoczesnym jej wydłużaniu w nieskończoność. Dlatego poczucie regresu wynika również z peryferyjnej pozycji w globalnym systemie władzy i gospodarki.

\section{Vrski}

Obserwując transformację z życia młodzieńczego, wspomaganego finansowo przez rodziców, do dorosłego i samodzielnego, można odnieść wrażenie, że nie ma ona końca. Przejście od bezpłatnych praktyk, pracy tymczasowej albo pracy niesatysfakcjonującej, poniżej zawodowych i finansowych ambicji, do pracy w wyuczonym zawodzie, satysfakcjonującej i stabilnej, zajmowało moim partnerom badawczym nawet kilkanaście lat, a czasami nigdy nie następowało. Goce

${ }^{20} \mathrm{~W}$ ramach reformy administracyjnej zmniejszono liczbę gmin z 123 do 84 i poszerzono między innymi granice Tetowa o czysto albańskie gminy wiejskie.

${ }_{21}$ Popova Šapka - kurort narciarski położony $20 \mathrm{~km}$ od Tetowa. 
przez całe swoje dorosłe życie pracował głównie bez umowy albo na umowy tymczasowe i bez ubezpieczenia socjalnego.

Po licencjacie dostałem się na bezpłatne praktyki zawodowe w kancelarii prawniczej i równocześnie robiłem magisterkę. Po obronie pracowałem w NGO przy projekcie dotyczącym korupcji w urzędzie miasta. [...] Starałem się, ciężko pracowałem, ale po zrealizowaniu projektu zostałem bezrobotny. Jeździłem na konferencje i prezentowałem efekty pracy, ale nikogo one nie interesowały. Następnie pracowałem przez trzy lata w systemie prowizyjnym w firmie windykacyjnej. Poza tym co roku jeżdżę nad Ochrydę pracować w barze. Spędzam tam całe wakacje.

Trudności na rynku pracy doświadczają wszyscy młodzi ludzie w Tetowie, bez względu na tożsamość etniczną. Niemniej rynek pracy dla Macedończyków w północno-zachodniej części kraju jest dodatkowo ograniczony brakiem kontaktów i znajomości języka swoich sąsiadów. Ponieważ większość mieszkańców Tetowa to Albańczycy, przedsiębiorcy wymagają komunikacji w języku albańskim. Brak znajomości tego języka jest ważną, ale nie jedyną trudnością w poszukiwaniu zatrudnienia. Rynek pracy w Tetowie jest silnie strzeżony przez sieć koneksji, czyli vrski, które wypracowuje się w procesie socjalizacji albo przez przynależność partyjną. Vrski nie tylko pomagają znaleźć pracę, ale też określają status danej osoby i wskazują, z kim należy utrzymywać alianse.

Innym sposobem na zdobycie kontaktów i pracy jest przynależność do partii politycznych. Afiliacja polityczna przydaje się zwłaszcza wtedy, gdy szuka się zatrudnienia w instytucjach publicznych. Te, choć oferują tylko przeciętne wynagrodzenie, gwarantują stałe zatrudnienie i regularne godziny pracy. Ale jak pokazuje przykład Gocego, aby dostać tę pracę, trzeba mieć koneksje polityczne, co wywołuje frustrację u młodych Macedończyków:

Bardzo trudno jest znaleźć pracę, która odpowiada wyuczonym kwalifikacjom, bez koneksji [vrski]. W Tetowie wszyscy są bardzo ze sobą związani. Jeśli chcesz znaleźć pracę, potrzebujesz kontaktów. Tutaj nie jest jak w Skopje, gdzie są inkubatory przedsiębiorczości, centra biznesu i NGO. Tutaj jest inaczej. [...] Osoby, które mają kwalifikacje, ale nie są członkami partii, pracują w zakładach bukmacherskich, kasynach albo w sklepach. Wszystko jest oparte na korupcji i kontaktach. Na przykład moją obecną pracę dostałem dzięki kontaktom, ale przynajmniej nie przez przynależność partyjną.

Tak więc vrski to sieć interesownych powiązań dających dostęp do pracy, usług instytucji publicznych, służby zdrowia oraz lepszych usług w sektorze prywatnym, pozwalających zrealizować określone przedsięwzięcia bez posiadania środków albo za gratyfikacje odroczone w czasie. Vrski to wbudowany mechanizm przetrwania, który zapewnia nieformalną strukturę ubezpieczenia społecznego powalającą przetrwać w trudnych czasach. Ta struktura ubezpieczeniowa pomaga rozwiązać przeszkody w codziennych życiowych zmaganiach, ale jest jawnym podziałem ryzyka, którego podstawą są wzajemność i obopólne zobowiązania, co w literaturze jest opisywane terminem „moralna ekonomia” (Scott 1976). Niemniej w przypadku dorastających mężczyzn, którzy również używali koneksji 
(vrski) w codziennej egzystencji, ich zasięg często bywał niewystarczający do rozwoju zawodowego i rodził stagnację.

W rozmowach z młodymi Macedończykami wybrzmiewała złość spowodowana sytuacją na rynku pracy, to jest pracą poniżej kwalifikacji, na tymczasowych umowach oraz z długimi okresami bezrobocia. Jak zauważyła Elena Fontanari, oczekiwanie i bezczynność spowodowana brakiem pracy może przyczynić się do zwiększenia pasywności oraz frustracji (Fontanari 2018: 77). Wśród moich rozmówców panowało przekonanie, że w Tetowie niewiele warta jest edukacja i doświadczenie zawodowe w przeciwieństwie do koneksji (vrski), zwłaszcza partyjnych, które potrafią utorować karierę zawodową. Przynależność partyjna wśród wielu młodych budziła odrazę. Była ona symbolem ucisku, niesprawiedliwości i nepotyzmu. Wszak vrski bezsprzecznie były potrzebne do znalezienia pracy i każdy się nimi posługiwał.

\section{Podmiotowość polityczna}

Poczucie własnej podmiotowości i sprawczości politycznej wśród młodych Macedończyków uległo zmianie. Moi rozmówcy, zwłaszcza starsi, na początku pierwszej dekady XXI wieku byli aktywni politycznie: angażowali się w działalność „młodzieżówek” partii politycznych, rozwieszali plakaty partyjne, wdawali się w bójki z Albańczykami i reprezentantami innych ugrupowań politycznych. Dzisiaj, poza nielicznymi wyjątkami, nikt z nich nie wychodzi na protesty i nie bierze udziału w plebiscytach. Kwestionują oni nie tylko dążenie polityków do poprawy sytuacji w kraju, ale również suwerenność państwa, a przez to wagę swoich głosów.

Moi rozmówcy, rozczarowani klasą polityczną i biznesową oraz przemianami społeczno-ekonomicznymi, pokładali bardzo małe nadzieje w wydarzeniach mających miejsce podczas moich badań terenowych: przedwczesnych wyborach parlamentarnych w 2016 roku, a później referendum w sprawie wejścia do UE i NATO pod nową nazwą Macedonia Północna. Dla młodych Macedończyków z Tetowa nie miało znaczenia, która partia wygra. Panowało powszechne przekonanie, że politycy nie reprezentują wyborców, tylko zabezpieczają swoje interesy.

Gdy zapytałem moich partnerów badawczych o przedwczesne wybory, a później o referendum, padały odpowiedzi: „będzie tak, jak chce Unia Europejska albo Stany Zjednoczone". Innym czynnikiem, który zniechęcał do głosowania, była inwigilacja i kontrola partyjna, która odstraszała od aktywności politycznej czy społecznej. Większość z moich partnerów badawczych nie brała udziału w protestach, nie uczestniczyła także w wyborach albo oddawała nieważny głos. Ivan, 37-letni samotny mężczyzna prowadzący kiosk, tłumaczył swój brak zainteresowania wyborami i protestami: 
Nie głosuję, bo wydaje mi się, że jak wspierasz jakąś partię, to bardzo łatwo potem oberwać. Jeśli partia, którą wspierasz, wygra, to możesz mieć z tego korzyści, na przykład pracę albo anulowany zaległy podatek. Jeśli przegra, możesz stracić pracę.

Wspieranie partii politycznych może nieść za sobą konsekwencje, tak samo pozytywne, jak i negatywne, które w procesie analizy korzyści i strat wydają się nie być tego warte.

Innym powodem nieoddawania głosu był brak wiary w wybory parlamentarne i referenda oraz pozytywne zmiany, jakie miałyby one nieść. Mogłem się o tym przekonać podczas jednego ze spotkań w kafanie z tymi samymi znajomymi, którzy przyglądali się demonstracji opisanej na początku artykułu. Podczas kolacji wywiązała się rozmowa na temat ważności oddawanych głosów. Jeden z mężczyzn powiedział, że jego głos się nie liczy, bo „wynik referendum będzie taki, jak władza sobie zarządzi, i nie ma znaczenia, czy społeczeństwo zagłosuje za czy przeciw”. Kiedy jedna z siedzących przy stole osób powiedziała, że należy oddać swój głos, bo to obywatelski obowiązek, reszta mężczyzn odpowiedziała chórem, że nie zamierzają sobie zaprzątać głowy polityką („ne sakam da se zamaram”), chociaż jednocześnie wybrzmiewały głosy sprzeciwu wobec wejścia do UE. Marko, 27-letni bezrobotny mężczyzna po szkole średniej, zauważył:

Jeśli wejdziemy do Unii, to wszyscy wyjadą z Macedonii, tak jak po przystąpieniu do Unii wszyscy wyjechali z Bułgarii. Zostaniemy tylko my, staniemy się częścią „Wielkiej Albanii” i będziemy musieli mówić po albańsku.

Ace $\mathrm{w}$ podobnym tonie zauważył, że nie zgadza się $\mathrm{z}$ tak postawionym pytaniem, odbiera je jako próbę manipulacji UE oraz Zorana Zaeva (premiera Macedonii) i będzie bojkotował referendum:

Jestem za wejściem do UE, ale przeciw NATO i przeciw zmianie nazwy. Będę bojkotował wybory, bo nie zgadzam się z tak postawionym pytaniem. Chociaż dla mnie byłoby lepiej, gdyby Macedonia weszła do Unii (z powodu planowanej emigracji - przyp. autora), ale dla tych, którzy tutaj zostaną, wejście do Unii oznacza całkowitą albanizację. Razem z reformami (akcesyjnymi przyp. autora) i zmianą nazwy przejdą też zmiany, które dadzą całkowitą autonomię Albańczykom i uznają język albański jako oficjalny język w całym kraju. Oznacza to, że wszyscy będą musieli znać albański i będzie on obowiązkowym językiem w macedońskich szkołach.

Bojkotowanie referendum było z jednej strony wyrazem braku wiary w pozytywne zmiany, jakie mogą zachodzić po wejściu do UE i NATO, a z drugiej wyrazem ukrytego sprzeciwu wobec zmiany nazwy, która równała się kapitulacji w kwestii obrony macedońskiej tożsamości nie tyle przed Grekami, ile Albańczykami.

Referendum budziło również kontrowersje z powodu zawarcia trzech, jakże różnych kwestii: tożsamości Macedończyków, rozpoczęcia procedury akcesyjnej do unii polityczno-gospodarczej i ostatniego, nie mniej ważnego punktu, to jest włączenia do Paktu Północnoatlantyckiego, który niecałe 20 lat wcześniej zbombardował ich północnych sąsiadów. Jak trafnie to opisał historyk i komentator 
Srdja Pavlović, pytanie postawione w referendum było równocześnie obietnicą i szantażem: zmiana nazwy otworzy drogę do UE i NATO, a odrzucenie tej propozycji skaże Macedonię na izolację i chaos (Pavlović 2018).

\section{Zakończenie}

Podczas ostatnich badań terenowych, latem 2018 roku, spostrzegłem, że większość moich partnerów badawczych wyjechała z Tetowa. Ten trend znajduje swoje potwierdzenie w danych statystycznych, które pokazują, że między 2010 a 2013 rokiem z Macedonii wyemigrowało co najmniej 59 tysięcy osób (Kostovska 2016). Emigracja wydaje się jedyną alternatywą dla tzw. śmieciowych umów o pracę i współdzielenia mieszkania $\mathrm{z}$ rodzicami. Ale przyczyną wyjazdów są nie tylko trudności na rynku pracy. Moi rozmówcy emigrują również z powodu rozczarowania niewydajną administracją publiczną, degradacją miasta i środowiska naturalnego czy braku ośrodków kultury i sportu. Emigracja jest wyrazem nieumiejętności przeżycia lub niezgody na warunki, jakie oferuje miejsce pochodzenia (zob. Hage 2009). Wyjazd z Tetowa jest wyrazem niechęci do dalszego oczekiwania na zmiany i pokładania nadziei w obietnicach polityków.

Wyjazd do Skopje albo za granicę z dwóch powodów okazuje się lepszym wyborem niż protestowanie. System klientelizmu etniczno-partyjnego sprawił, że wielu mieszkańców obawiało się represji ze strony partii rządzącej z powodu wyrażania swojej opinii. Innym powodem, jak twierdzę - kluczowym, był brak wiary w znaczenie protestów i zmianę władz, rozczarowanie otaczającą rzeczywistością bez względu na barwy partii rządzących. Młodzi Macedończycy z Tetowa stracili wiarę w ważność swoich głosów wyborczych, ponieważ wybory nosiły znaki manipulacji. Poczucie podmiotowości politycznej spadło również dlatego, że moi rozmówcy powątpiewali w suwerenność kraju (będzie tak, jak chcą UE i USA, a nie tak, jak zagłosują obywatele). Greenberg twierdzi, że rozczarowanie jest stałym elementem demokracji (Greenberg 2014: 9). Uważam, że jest wprost przeciwnie. Rozczarowanie prowadzi do podważania demokracji i jej zmierzchu. Rozczarowanie jest odcięciem się od nadziei, którą niesie przyszłość, jest wyrazem bezsilności i zwątpienia w zmiany. Rozczarowanie wyraża się w utracie wiary w podmiotowość polityczną, państwo, demokrację. Niemniej apatia polityczna nie wynika $\mathrm{z}$ wsobnych wad jednostki, ale jest reakcją na warunki, jakie narzuca pozycja Macedonii w globalnym systemie społeczno-gospodarczym.

Rozczarowanie rzeczywiście może być afektywne, ale nie zawsze ma kształt publicznego protestu. Czasami ta walka przybiera kształt ukrytego sprzeciwu bojkotu wyborów, tak jak to się działo podczas referendum w sprawie zmiany nazwy i wejścia do UE i NATO we wrześniu 2018 roku. Natomiast częściej rozczarowanie motywuje do emigracji, co można odczytywać jako aktywną próbę zmiany otaczającej rzeczywistości. 


\section{Podziękowania}

Badania terenowe oraz przygotowanie tekstu były możliwe dzięki projektowi badawczemu PRELUDIUM Narodowego Centrum Nauki pt. „Transformacja miast postjugosłowiańskich. Antropologiczne studium przypadku Tetowa w Macedonii” (FYROM) o numerze rejestracyjnym 2015/17/N/HS6/00694.

\section{Bibliografia}

Bandak A., Janeja M.K.

2018 Introduction: Worth the Wait, w: M.K. Janeja (ed.), Ethnographies of Waiting. Doubt, Hope and Uncertainty, London-New York, s. 1-41.

Bieber F.

2004 Institutionalization of Ethnicity in the Western Balkans: Managing Change in Deeply Divided Societies, ECMI Working Paper, nr 19, Flensburg.

Brentin D., Bieber F.

2018 Introduction: Social Movements and Protests in Southeast Europe - A New Tragedy of the Commons?, w: D. Brentin, F. Bieber (eds.), Social Movements in the Balkans: Rebellion and Protest from Maribor to Taksim, London, s. 1-9.

Fontanari E.

2018 Lives in Transit: An Ethnographic Study of Refugees' Subjectivity across European Borders, London-New York.

Frederiksen M.D.

2018 Waiting for Nothing: Nihilism, Doubt and Difference without Difference in Post-Revolutionary Georgia, w: M.K. Janeja, A. Bandak (eds.), Ethnographies of Waiting. Doubt, Hope and Uncertainty, London-New York, s. 163-180.

Graan A.

2013 Counterfeiting the Nation? Skopje 2014 and the Politics of Nation Branding in Macedonia, „Cultural Anthropology”, nr 28 (1), s. 161-179.

Greenberg J.

2014 After the Revolution: Youth, Democracy, and the Politics of Disappointment in Serbia, Stanford.

Hage G.

2009 Waiting Out the Crisis: On Stuckedness and Governmentality, w: H. Ghassan (ed.), Waiting, Carlton, Vic.

Jansen S.

2009 After the Red Passport: Towards an Anthropology of the Everyday Geopolitics of Entrapment in the EU's 'Immediate Outside', ,The Journal of the Royal Anthropological Institute", nr 15 (4), s. 815-832.

2015 Yearnings in the Meantime: „Normal Lives” and the State in a Sarajevo Apartment Complex, New York-Oxford.

Jovanović D.

2018 Prosperous Pollutants: Bargaining with Risks and Forging Hopes in an Industrial Town in Eastern Serbia, „Ethnos”, nr 83 (3), s. 489-504. 
Koselleck R.

2004 Futures Past: On the Semantics of Historical Time, przeł. K. Tribe, New York-Chichester, West Sussex.

Kostovska I.

2016 Eurostat Data Reveal Scale of Macedonian Exodus, „Balkan Inside”, February 1, https://www.balkaninsight.com/2016/02/01/eurostat-data-reveal-exodus-of-macedonians-01-29-2016/(dostęp: 18.10.2018).

Landsberg A.

2004 Prosthetic Memory: The Transformation of American Remembrance in the Age of Mass Culture, New York.

Lyatord J.-F.

1984 The Postmodern Condition: A Report on Knowledge, Minneapolis.

Majewski P.

2013 (Re)konstrukcje narodu, Gdańsk.

Maksimović M.

2017 Unattainable Past, Unsatisfying Present - Yugonostalgia: An Omen of a Better Future?, „Nationalities Papers”, nr 45 (6), s. 1066-1081.

Mattioli F.

2016 Losing Values: Illiquidity, Personhood, and the Return of Authoritarianism in Skopje, Macedonia, Unpublished PhD dissertation at The Graduate Center, The City University of New York.

Metzger J.

2010 Richard Rorty's Disenchanted Liberalism, „Contemporary Pragmatism”, nr 7 (1), s. 7-128.

Neofotistos P.V.

2012 The Risk of War: Everyday Sociality in the Republic of Macedonia, Philadelphia.

Pavlović S.

2018 Nome nest omen, „Nova Makedonija”, October 10, https://www. novamakedonija.com.mk/mislenja/kolumni/nomen-est-omen-\%D0\%B8\%D0\%BC\%D0\%B5\%D1\%82\%D0\%BE-\%D0\%B5-\%D1\%81\%D1\%83\%D0 \%B4\%D0\%B1\%D0\%B8\%D0\%BD\%D0\%B0/?fbclid=IwAR1OJ2iVSJKjr8Rwxa9qh1IM cOKa0Dh_2OnJWJjTe4KE3caKpYdXRPfxvSw (dostęp: 18.10.2018).

Pichler R.

2009 Migration, Ritual and Ethnic Conflict. A Study of Wedding Ceremonies of Albanian Transmigrants from the Republic of Macedonia, „Ethnologia Balkanica”, nr 13, s. $211-230$.

Procupez V.

2015 The Need for Patience. The Politics of Housing Emergency in Buenos Aires, „Current Anthropology", nr 56 (11), s. 55-65.

Radnitz S.

2010 Weapons of the Wealthy: Predatory Regimes and Elite-Led Protests in Central Asia, Ithaca.

Rydzewski R.

2018 Mobilność $w$ czasach zamkniętych granic - notatki z badań terenowych $w$ Serbii, „Łódzkie Studia Etnograficzne”, nr 56, s. 161-176.

Understanding the Albanians Return to Macedonia. Motivations and Impact of Albanian Returnees on Local Community, „Ethnologia Balkanica” [w druku]. 
Scott J.C.

1976 The Moral Economy of the Peasant: Rebellion and Subsistence in Southeast Asia, New Haven.

Thiessen I.

2007 Waiting for Macedonia: Identity in a Changing World, Toronto.

Vangeli A.

2011 Nation-Building Ancient Macedonian Style: The Origins and the Effects of the So-Called Antiquization in Macedonia, „Nationalities Papers”, nr 39 (1), s. 13-32. Zigon J.

2018 Hope and Waiting in Post-Soviet Moscow Ethnography of Waiting, w: M.K. Janeja, A. Bandak (eds.), Ethnographies of Waiting. Doubt, Hope and Uncertainty, LondonNew York, s. 65-87. 